Jurnal KONTEKSTUAL

Volume 01, No. 1, Agustus 2019, pp.26-32

\title{
PENGARUH MINAT DAN KEMAMPUAN MEMBACA PESERTA DIDIK DALAM MEMAHAMI TEKS BACAAN
}

\author{
Puji Astuti ${ }^{1}$, Atikah Mumpuni ${ }^{* 2}$, Budi Adjar Pranoto ${ }^{3}$, \\ ${ }^{1,2,3} 2$ Prodi Pendidikan Guru Sekolah Dasar, Fakultas Keguruan dan Ilmu Pendidikan \\ Universitas Muhadi Setiabudi Brebes, Indonesia \\ Email corresponden: * atikahmumpuni@gmail.com
}

\begin{abstract}
ABSTRAK
Tujuan dari penelitian ini untuk mengetahui pengaruh antara minat membaca dengan memahami teks bacaan pada peserta didik kelas IV di SD Negeri Bulakamba 01 dan untuk mengetahui pengaruh antara kemampuan membaca dengan memahami teks bacaan pada peserta didik kelas IV di SD Negeri Bulakamba 01. Penelitian ini menggunakan metode kuantitatif dengan desain penelitian korelasi. Populasi dalam penelitian ini yaitu siswa kelas IV SD Negeri Bulakamba 01 yang berjumlah 30 peserta didik. Teknik sampling yang digunakan teknik sampling jenuh dengan jumlah sampel 30 peserta didik. Teknik pengumpulan data dalam penelitian ini dengan angket, observasi dan tes. Teknik analisis data yang digunakan adalah stsistik deskripsi, uji normalitas, uji linearitas dilakukan sebagai uji prasyarat hipotesis., uji $t$ untuk pengujian hipotesis. Hasil penelitian ini menunjukan bahwa hasil uji t minat terhadap memahami teks bacaan diperoleh hasil $t_{\text {hitung }}=2.171$, yang berarti bahwa $t_{\text {hitung }}>t_{\text {tabel }}$ yaitu 2.171> 2,052. Sedangkan, hasil uji t kemampuan membaca terhadap memahami teks bacaan diperoleh hasil $t_{\text {hitung }}=3.232$, yang berarti $t_{\text {hitung }}>t_{\text {tabel }}$ yaitu $3.232>2,034$, yang berarti bahwa Ho ditolak dan Ha diterima. Jadi, simpulan dari penelitian ini yaitu ada pengaruh minat dan kemampuan membaca peserta didik kelas IV dalam memahami teks bacaan di SD Negeri Bulakamba 01.
\end{abstract}

Kata Kunci: Minat Membaca, Kemampuan Membaca, Memahami Teks Bacaan

\begin{abstract}
The purpose of this study was to determine the effect of reading interest by understanding reading texts in grade IV students in SD Negeri Bulakamba 01 and to determine the effect of reading ability by understanding reading texts in grade IV students at SD Negeri Bulakamba 01. This study uses the method quantitative research correlation design. The population in this study were grade IV students of SD Negeri Bulakamba 01, amounting to 30 students. The sampling technique used is saturated sampling technique with a sample size of 30 students. Data collection techniques in this study were questionnaire, observation and test. The data analysis technique used is description statistics, normality test, linearity test is done as a prerequisite hypothesis test, $t$ test for hypothesis testing. The results of this study indicate that the results of the $t$ test of interest in understanding the text of the reading obtained tcount $=$ 2.171 , which means that tcount $>$ ttable is 2.171> 2.052. Meanwhile, the results of the t test of reading ability to comprehend the reading text obtained the results of tcount $=3.232$, which means tcount> ttable is 3.232> 2.034, which means that Ho is rejected and Ha is accepted. So, the conclusion of this study is that there is an influence of interest in and ability to read grade $I V$ students in understanding reading texts in SD Negeri Bulakamba 01.
\end{abstract}

Keywords: Interest in Reading, Reading Ability, Understanding Reading Text

Submitted: 2019, Accepted: 2019, Published: Agustus 2019

ISSN: xxxx-Xxxxx (online), Website: http://jurnal.umus.ac.id/index.php/kontekstual 
Jurnal KONTEKSTUAL, Volume 01, No. 1, Agustus 2019, pp. 26-32

\section{PENDAHULUAN}

Pendidikan merupakan hal yang terpenting dalam kehidupan manusia karena setiap manusia berhak untuk selalu berkembang dalam pendidikan. Berdasarkan Undang-undang Sistem Pendidikan Nasional No. 20 Tahun 2003 Bab III Pasal 4 Butir 5 menyatakan bahwa,"Pendidikan diselenggarakan dengan mengembangkan budaya membaca, menulis, dan berhitung bagi segenap warga masyarakat".

Sesuai dengan hal tersebut, Indonesia perlu memposisikan dirinya menjadi bangsa yang berbudaya baca tulis, maka perlu dilakukan upaya pengembangan, baik melalui jalur pendidikan formal maupun nonformal. Pengembangan melalui pendidikan formal dimulai dari sekolah dasar yang berfungsi sebagai pusat budaya dan pembudayaan baca tulis. Jadi sekolah harus membekali lulusannya dengan kemampuan dan keterampilan dasar yang memadai.

Minat membaca pada anak disebabkan oleh buku yang tidak menarik dan mahal sehingga hanya kalangan menengah keatas saja yang dapat membelinya. Hampir sebagian besar penerbit enggan menerbitkan buku bacaan ringan, seperti komik. Padahal, untuk menjadikan anak gemar membaca bisa dimulai dengan membaca buku-buku bacaan ringan. Menurut [1] minat baca ialah keinginan yang kuat disertai usahausaha seseorang untuk membaca.

Tingkat kesiapan anak dalam menerima pelajaran membaca, tidaklah sama. Kesiapan membaca ini banyak dipengaruhi oleh faktor lingkungan, baik lingkungan keluarga (rumah) maupun lingkungan luar rumah. Dalam hal ini, orang tualah yang berperan mengembangkan kemampuan membaca pada anak.
Berdasarkan teori dan permasalahan yang telah diuraikan, maka penelitian yang berjudul "Pengaruh Minat dan Kemampuan Membaca Peserta Didik Kelas IV Dalam Memahami Teks Bacaan Fiksi dan Nonfiksi di SDN Bulakamba 01", sanggat perlu untuk dilaksanakaan.

Berdasarkan latar belakang yang telah di uraikan maka dapat dirumuskan masalah sebgai berikut. 1) Apakah ada pengaruh antara minat membaca dengan memahami teks bacaan fiksi dan nonfiksi pada peserta didik kelas IV di SD Negeri Bulakamba 01? 2) Apakah ada pengaruh antara kemampuan membaca dengan memahami teks bacaan fiksi dan nonfiksi pada peserta didik kelas IV di SD Negeri Bulakamba 01?

Tujuan di adakannya penelitian ini adalah. 1) Untuk mengetahui pengaruh antara minat membaca dengan memahami teks bacaan fiksi dan nonfiksi pada peserta didik kelas IV di SD Negeri Bulakamba 01. 2) Untuk mengetahui pengaruh antara kemampuan membaca dengan memahami teks bacaan fiksi dan nonfiksi pada peserta didik kelas IV di SD Negeri Bulakamba 01.

\section{KAJIAN TEORI}

Minat adalah sesuatu yang sangat penting bagi seseorang dalam melakukan kegiatan dengan baik, sebagai aspek kejiwaan, minat tidak saja dapat mewarnai perilaku seseorang, tetapi lebih dari itu minat mendorong untuk melakukan sesuatu kegiatan dan menyebabkan seseorang menaruh perhatian dan merelakan dirinya untuk tertarik pada suatu kegiatan[2]. Minat juga dapat diartikan sebagai suatu kesukaan, kegemaran atau kesenanagan akan sesuatu[3].

Beberapa indikator yang mengacu pada kemampuan untuk 
mengelola berbagai kegiatan yang mampu menumbuhkan kegemaran membaca[1]. Indikator yang dimaksud antara lain sebagai berikut.

1) Menganjurkan untuk membaca buku

2) Menceritakan satu kejadian yang dibaca dari berbagi sumber (misalnya buku, koran, majalah) sebagai titik tolak pembelajaran

3) Meminta menceritakan peristiwa yang pernah mereka baca

4) Membaca secara berkesinambungan

Membaca adalah suatu proses yang dilakukan serta dipergunakan oleh pembaca untuk memperoleh pesan, yang hendak disampaikan oleh penulis melalui media kata-kata atau bahasa tulis [4]. Selain itu kemampuan membaca merupakan sesuatu yang vital dalam suatu masyarakat terpelajar[1].

Banyak faktor yang mempengaruhi kemampuan membaca, baik membaca permulaan maupun membaca lanjut (membaca pemahaman). Faktor-faktor yang mempengaruhi membaca permulaan yaitu[1]:

1) Faktor Fisiologis

Faktor fisiologis mencakup kesehatan fisik, pertimbangan neurologis, dan jenis kelamin. Kelelahan juga merupakan kondisi yang tidak menguntukan bagi anak untuk belajar, khususnya belajar membaca.

2) Faktor Intelektual Istilah intelegensi didefinisikan oleh Heinz sebagai suatu kegiatan berpikir yang terdiri dari pemahaman yang esensial tentang situasi yang diberikan dan meresponya secara tepat.

3) Faktor Lingkungan

Faktor lingkungan juga memengaruhi kemajuan kemampuan membaca siswa. Faktor lingkungan itu mencakup 1) latar belakang dan pengalaman siswa dirumah, dan 2) sosial ekonomi keluarga siswa.

4) Faktor Psikologis

Faktor lain yang juga memengaruhi kemajuan kemampuan membaca anak adalah faktor psikologi. Faktor ini mencakup 1) motivasi, 2) minat, dan 3) kematangan sosial, emosi dan penyesuaian diri.

Kajian teori tentang kemampuan membaca diatas, dalam penelitian ini indikator aspek kemampuan membaca yang dijadikan alat ukur meliputi: kemampuan siswa dalam mengucapkan kata-kata dan memahami makna kata dalam bacaan.

Strategi adalah ilmu kiat didalam memanfaatkan segala sumber yang dimiliki dan atau yang dapat dikerahkan untuk mencapai tujuan yang telah ditetapkan. Pada dasarnya, strategi membaca menggambarkan bagaimana pembaca memproses bacaan sehingga dia memperoleh pemahaman terhadap bacaan tersebut.

Dalam penelitian ini, yang menjadi indikator memahami teks bacaan untuk digunakan dalam penyusunan instrumen adalah:

Kompetensi Dasar (KD)

1.7 Mengagali pengetahuan baru yang didapat dari teks nonfiksi

4.7 Menyampaikan pengetahuan baru dari teks nonfiksi kedalam tulisan dengan bahasa sendiri

1.8 Membandingkan hal yang sudah diketahui dengan yang baru diketahui dari teks nonfiksi

1.9 Mencermati tokoh-tokoh yang terdapat pada teks fiksi

Indikator

3.7.1 Menyampaikan jawaban dari pertanyaan yang diajukan berdasarkan teks 
Jurnal KONTEKSTUAL, Volume 01, No. 1, Agustus 2019, pp. 26-32

4.7.1 Menceritakan kembali isi teks berdasarkan jawaban yang ada

3.8.1 Menyebutkan informasi yang diketahui tentang salah satu pahlawan nasional indonesia

1.9.1 Mengidentifikasi tokoh, sifat tokoh dan inti cerita fiksi

\section{METODE PENELITIAN}

Penelitian ini merupakan penelitian kuantitatif dengan desain penelitia korelasional. Penelitian dilaksanakan di kelas IV SD Negeri Bulakamba 01. Pelaksanaan dilakukan pada bulan Maret sampai dengan Juli 2019.

Populasi pada penelitian ini adalah semua siswa kelas IV yang berada di SD Negeri Bulakamba 01 tahun ajaran 2018/2019 yang berjumlah 30 siswa.

Sampel pada penelitian ini sebanyak 30 siswa kelas IV SD Negeri Bulakamba 01 tahun ajaran 2018/2019.Teknik sampel yang akan digunakan dalam penelitian ini adalah Sampling Jenuh (Sensus).

Teknik pengumpulan data dalam penelitian ini adalah 1) Kuesioner. kuesioner ini digunakan untuk memperoleh data tentang minat membaca. 2) Observasi lembar dalam penelitian ini Lembar Observasi di gunakan untuk mengambil data kemampuan membaca. 3) Tes digunakan untuk memperoleh data memahami teks bacaan.

Tahap pengolahan data yang dilakukan dalam penelitian ini meliputi.

1. Data hasil penelitian

2. Uji prasyarat Hipotesis

3. Uji hipotesis

\section{HASIL DAN PEMBAHASAN Hasil Penelitian}

1. Pengaruh Antara Minat Membaca dengan Memahami Teks Bacaan Pada Peserta Didik Kelas IV di SD Negeri Bulakamba 01

Berdasarkan uji normalitas di atas menngunakan KolmogorovSmirnov diperoleh untuk minat peserta menunjukkan bahwa hasil yang diperoleh lebih besar dari 0,05 $(0,929>0,05)$ sehingga dapat disimpulkan bahwa data tersebut berdistribusi normal. Kemudian nilai sig. untuk memahami teks bacaan juga lebih besar dari $0,05(0,613>$ $0,05)$. Jadi dari uji normalitas di atas menunjukkan bahwa data tersebut berdistribusi normal.

Berdasarkan hasil uji linearitas pada output 'Anova Table' di atas, diketahui bahwa nilai signifikansi 0,338>0,05 maka dapat disimpulkan bahwa terdapat hubungan linear variabel minat dengan memahami teks bacaan.

Berdasarkan Nilai uji $\mathrm{t}$ thitung $=2.171>2.052$ atau thitung $>$ ttabel dan $0,039<0,05$ atau nilai signifikansi $<0,05$. Sehingga dapat disimpulkan bahwa H1 diterima yang berarti terdapat pengaruh $\mathrm{X} 1$ terhadap Y.

2. Pengaruh Antara Kemampuan Membaca dengan Memahami Teks Bacaan Pada Peserta Didik Kelas IV di SD Negeri Bulakamba 01

Berdasarkan uji normalitas di atas menngunakan KolmogorovSmirnov diperoleh kemampuan membaca peserta didik sebesar $(0,516>0,05)$ sehingga dapat disimpulkan bahwa data tersebut berdistribusi normal. Kemudian nilai sig. untuk memahami teks bacaan juga lebih besar dari $0,05(0,652>$ $0,05)$. Jadi dari uji normalitas di atas menunjukkan bahwa data tersebut berdistribusi normal. 
Jurnal KONTEKSTUAL

Volume 01, No. 1, Agustus 2019, pp. 26-32

\begin{abstract}
Berdasarkan hasil uji linearitas pada output 'Anova Table'di atas, diketahui bahwa nilai signifikansi 0,104 > 0,05 maka dapat disimpulkan bahwa terdapat hubungan linear variabel kemampuan membaca dengan memahami teks bacaan.

Berdasarkan uji t nilai thitung $=3.232$ dan signifikansinya sebesar 0,003. Dari hasil perhitungan tersebut dapat diketahui bahwa 3.232 $>2.052$ atau thitung $>$ ttabel dan $0,003<0,05$ atau nilai signifikansi $<$ 0,05 . Sehingga dapat disimpulkan bahwa H2 diterima yang berarti terdapat pengaruh $\mathrm{X} 2$ terhadap $\mathrm{Y}$.
\end{abstract}

\section{Pembahasan}

1. Pengaruh Minat (X1) Terhadap Memahami Teks Bacaan (Y)

Setelah dilakukan analisis dengan uji $\mathrm{t}$ menggunakan aplikasi program SPSS versi 16, diperoleh hasil thitung > ttabel yaitu nilai thitung = 2.171 dan nilai ttabel $=2,052$ maka $2.171>2,052$. nilai signifikansi $<0,05$ yaitu 0,039 . Hasil thitung $>$ ttabel dan signifikansi $0,039<0,05$, Hal tersebut berarti bahwa hipotesis pertama (Ha-1) yang diajukan peneliti diterima yang berarti bahwa ada pengaruh yang positif dan signifikan antara variabel minat terhadap memahami teks bacaan kelas IV di SD Negeri Bulakamba 01. Hal ini dapat diperkuat dari penelitian terdahulu yang dilakukan oleh Najamiah dengan judul penelitian "Pengaruh Minat Baca terhadap Kemampuan Memahami bacaan Peserta Didik Kelas IV SD Negeri Gunung Sari I Kec”. Hasil penelitian menunjukkan adanya pengaruh minat baca terhadap kemampuan memahami bacaan peserta didik. Berdasarkan hasil analisis data menggunakan statistik deskriptif untuk variabel minat baca diperoleh nilai ratarata 135,19 berada pada kategori sedang dari skor angket terendah 83 dan skor tertinggi 160. Pada variabel kemampuan literasi membaca diperoleh nilai ratarata 79,69 berada pada kategori sedang dari skor tes nilai terrendah 42 dan skor tertinggi 100. Adapun hasil analisis statistik inferensial (Analisis Regresi Linear Sederhana) diperoleh Fhitung $=$ $14.759>\mathrm{F} 0,05(1) 60=4,00$. Dengan demikian dapat disimpulkan bahwa terdapat pengaruh minat baca terhadap kemampuan memahami bacaan peserta didik kelas IV SD Negeri Gunung Sari 1 Kec. Rappocini Kota Makassar.

Penelitian yang dilakukan oleh Fitriana tahun 2012 dengan judul "Hubungan Antara Minat Baca dengan Kemampuan Memahami Bacaan Siswa Kelas V SD Se-Gugus II Kecamatan Gedongtengen Kota Yogyakarta Tahun Ajaran 2011/2012". hasil penelitian menunjukkan ada hubungan yang positif dan signifikan antara minat baca dengan kemampuan memahami bacaan. Dari hasil perhitungan korelasi ProductMoment, diperoleh rxy sebesar 0,434. Nilai $r$ tabel dengan $n=89$ pada taraf signifikansi 0,05 sebesar 0,207. Dengan demikian, $r$ hitung lebih besar dari $r$ tabel $(0,434>0,207)$. Hal ini menunjukkan bahwa semakin tinggi minat baca siswa maka semakin tinggi pula kemampuan memahami bacaannya, begitu juga sebaliknya.

2. PengaruhKemampuan Membaca $\left(\mathrm{X}_{2}\right)$ Terhadap Memahami Teks Bacaan (Y)

Setelah dilakukan analisis dengan uji $t$ menggunakan aplikasi program SPSS versi 16, diperoleh hasil thitung > ttabel yaitu nilai thitung $=$ 3.232 dan nilai ttabel $=2,052$ maka $3.232>2,052$. nilai signifikansi < 0,05 yaitu 0,003 . Hasil thitung $>$ ttabel dan signifikansi $0,003<0,05$, Hal tersebut berarti bahwa hipotesis pertama (Ha-2) yang diajukan peneliti diterima yang berarti bahwa ada pengaruh yang 
Jurnal KONTEKSTUAL, Volume 01, No. 1, Agustus 2019, pp. 26-32

positif dan signifikan antara variabel kemampuan membaca terhadap memahami teks bacaan kelas IV di SD Negeri Bulakamba 01. Hal ini dapat diperkuat dari penelitian terdahulu yang dilakukan oleh Oktaviasari, Hasil analisis menunjukkan adanya hubungan positif dan signifikan antara kemampuan membaca pemahaman dengan kemampuan mengapresiasi cerita pendek yaitu sebesar 0,828 termasuk dalam kategori sangat kuat. Perhitungan persamaan regresi menunjukkan $\hat{\mathrm{Y}}=0,611+0,816 \mathrm{X}$, artinya apabila nilai kemampuan membaca pemahaman bertambah satu satuan, maka nilai kemampuan mengapresiasi cerita pendek akan bertambah 0,816. Nilai determinasi kemampuan membaca pemahaman terhadap kemampuan mengapresiasi cerita pendek sebesar $68,6 \%$, artinya kemampuan mengapresiasi cerita pendek $68,6 \%$ ditentukan oleh tingginya kemampuan membaca pemahaman, dan $31,4 \%$ ditentukan oleh factor lainnya, misalnya tingkat intelegensi siswa. Berdasarkan hasil penelitian di atas dapat dinyatakan bahwa terdapat hubungan positif dan pengaruh signifikan antara kemampuan membaca pemahaman dengan kemampuan mengapresiasi cerita pendek. Hal ini harus menjadi perhatian guru dalam proses pembelajaran, guru perlu merencanakan kegiatan-kegiatan yang dapat menunjang peningkatan keterampilan membaca siswa.

Penelitian yang dilakukan oleh Khofiah dengan judul "Hubungan Minat Baca dengan Kemampuan Membaca Pemahaman Siswa Kelas Tinggi SDN 1 Karangsari, Kecamatan Pengasih,Kabupaten Kulon Progo Tahun Ajaran 2014/ 2015". Hasil pengujian hipotesis menunjukkan harga koefisien korelasi ( $\mathrm{r}$ hitung) $>\mathrm{r}$ tabel $(0,590>0,234)$ dengan taraf signifikansi sebesar 5\% dengan jumlah $\mathrm{N}=71$. Harga koefisien korelasi tersebut mengindikasikan adanya hubungan yang positif antara minat baca dengan kemampuan membaca pemahaman siswa kelas tinggi SD N 1 Karangsari, Kecamatan Pengasih, Kabupaten Kulon Progo tahun ajaran 2014/ 2015. Hal ini memiliki arti bahwa setiap kenaikan variabel minat baca akan mempengaruhi kenaikan variabel kemampuan membaca pemahaman.

\section{SIMPULAN \\ 1. Simpulan}

Berdasarkan hasil penelitian dan pembahasan maka simpulan ini adalah sebagai berikut: 1 . Terdapat pengaruh antara minat membaca dengan memahami teks bacaan kelas IV di SDN Bulakamba 01. Hal ini di tunjukan pada $\mathrm{t}$ hitung $>\mathrm{t}$ table yaitu $2.171>2,052$. dan 0,039 $<0,05$ atau nilai signifikansi < 0,05 . Maka hipotesis pertama (Ha1) diterima, yang berarti minat berpengaruh terhadap memahami teks bacaan kelas IV di SDN Bulakamba 01. 2. Terdapat pengaruh antara kemampuan membaca dengan memahami teks bacaan kelas IV di SDN Bulakamba 01. Hal ini di tunjukan pada thitung $>$ t table yaitu $3.232>$ 2,052. dan $0,003<0,05$ atau nilai signifikansi $<0,05$. Maka hipotesis kedua (Ha2) diterima, yang berarti kemampuan membaca berpengaruh terhadap memahami teks bacaan kelas IV di SDN Bulakamba 01.

2. Saran

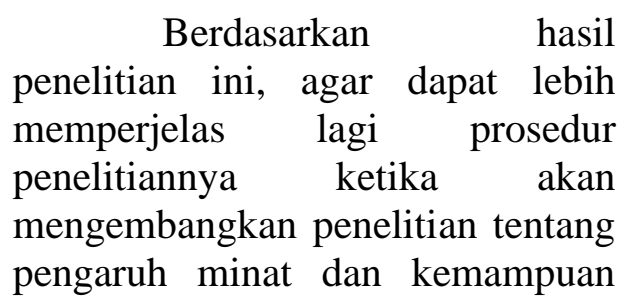


Jurnal KONTEKSTUAL

Volume 01, No. 1, Agustus 2019, pp. 26-32

membaca peserta didik kelas IV dalam memahami teks bacaan agar mampu menyempurnakan skripsi yang sudah ada. 2) Bagi Sekolah diharapkan siswa meningkatkan minat baca karena di sekolah, kepala sekolah dan guru telah menyiapkan banyak tempat dan buku untuk dibaca seperti gerobak baca, taman baca, café baca dan lain-lain sehingga prestasi belajar semakin meningkat, disetiap ruang kelas seharusnya di sediakan pojok perpustakan agar siswa akan lebih rajin dalm membaca

\section{REFERENCES}

[1] Rahim, F. 2008. Pengajaran Membaca Disekolah Dasar. Jakarta : Bumi Aksara.

[2] Meity, I. H,\& Ramdani, I. 2015. Menumbuhkan Minat Membaca Pada Anak Usia Dini. Jakarta Timur : Luxima Metro Media

[3] Susanto, A. 2013. Teori Belajar dan Pembelajaran di Sekolah Dasar. Jakarta: Prenada Medi Group.

[4] Tarigan , Henry Guntur. 2008. Membaca Sebagai Suatu keterampilan Bahasa. Bandung: Angkasa. 